\author{
ANNA MARIA ZOŃ \\ ORCID: 0000-0002-4286-4486 \\ Uniwersytet Medyczny im. Piastów Śląskich we Wrocławiu \\ 4. Wojskowy Szpital Kliniczny z Polikliniką SP ZOZ \\ KATARZYNA MARIA ZOŃ \\ ORCID: 0000-0001-5175-2091 \\ Uniwersytet Wrocławski
}

\title{
PRAWNE I MEDYCZNE ASPEKTY MODYFIKACJI AKTYWNOŚCI WSZCZEPIALNYCH URZACDZEŃ DO ELEKTROTERAPII SERCA U PACJENTÓW U KRESU ŻYCIA
}

\begin{abstract}
Abstrakt: Choroby układu krążenia przyczyniają się do prawie połowy zgonów w Polsce. Określone zaburzenia czynności serca leczone są przy pomocy wszczepialnych urządzeń do elektroterapii serca. Celem pracy jest kompleksowa analiza problematyki modyfikacji funkcji implantowanych urządzeń do elektroterapii na przykładzie dwóch z nich: stymulatora serca (PM) i kardiowertera-defibrylatora (ICD). W powyższym kontekście znaczenie ma zaakcentowanie statusu prawnego tych urządzeń oraz wyjaśnienie podstawowych kwestii medycznych (rodzaje urządzeń, występujące różnice i podobieństwa), których przedstawienie jest konieczne do prowadzenia dalszych rozważań. W tym zakresie omówiono zagadnienie modyfikacji funkcji urządzeń do elektroterapii zarówno w ujęciu prawnym, jak i medycznym. Poruszono zatem problematykę zgody uprawnionego podmiotu oraz zakresu obowiązku informacyjnego. Wskazano też, na czym może polegać modyfikacja aktywności urządzeń, z jakich przyczyn, kiedy oraz w jakim zakresie się jej dokonuje. Dodatkowo w świetle tytułowego zagadnienia rozważono, czy, a jeśli tak, to w jakich przypadkach przedmiotowa terapia może być traktowana jako uporczywa. Rozważania zostały zakończone wnioskami z przeprowadzonej analizy.
\end{abstract}

Słowa kluczowe: zgoda pacjenta, obowiązek informacyjny, autonomia pacjenta, wszczepialne urządzenia do elektroterapii serca, uporczywa terapia 


\section{WPROWADZENIE}

Choroby układu krążenia są obecnie przyczyną prawie połowy zgonów w Polsce $^{1}$. Określone zaburzenia czynności serca leczy się, implantując elektroniczne urządzenia do elektroterapii. Tytułem wprowadzenia warto zwrócić uwagę, iż metoda ta nie jest rozwiązaniem nowym. W dniu 8 października 1958 roku w Szwecji kardiochirurg Åke Senning wszczepił pierwszy na świecie stymulator serca, który zaprojektował Rune Elmquist ${ }^{2}$. W Polsce taki zabieg został przeprowadzony we wrześniu 1963 roku w Gdańsku³ ${ }^{3}$ Natomiast pierwszy kardiowerter na świecie, skonstruowany przez Mortona Mowera i Michela Mirowskiego, wszczepiono dnia 4 lutego 1980 roku w USA4 . W Polsce zaś implantacja urządzenia odbyła się w 1987 roku w Katowicach ${ }^{5}$.

Już na wstępie warto podkreślić, że ogólny wzrost liczby osób z elektronicznymi urządzeniami do elektroterapii wynika przede wszystkim z czynników medycznych (rozszerzenie wskazań do stosowania), a także demograficznych (wydłużanie się średniej życia). Dodatkowo ta grupa pacjentów staje się coraz liczniejsza w populacji osób starszych oraz osób znajdujących się u kresu życia. Dowodzi to bardzo istotnego znaczenia praktycznego zagadnienia, co uzasadnia przeprowadzenie pogłębionych rozważań prawnych i medycznych w tym zakresie. Ze względu na ograniczone ramy przedmiotowe niniejsza praca nie obejmuje aspektów etycznych.

Celem artykułu jest dokonanie kompleksowej analizy problematyki modyfikacji funkcji implantowanych urządzeń do elektroterapii na przykładzie dwóch z nich: stymulatora serca (PM) i kardiowertera-defibrylatora (ICD), uwzględniającej zarówno aspekt prawny, jak i medyczny. Do wyznaczenia ram przedmiotowych pracy niezbędne będzie dokonanie oceny statusu prawnego tych urządzeń oraz wyjaśnienie zagadnień medycznych (rodzaje urządzeń, występujące różnice i podobieństwa). Kolejny element poruszanej problematyki - kwestia modyfikacji funkcji urządzeń do elektroterapii - omówiony zostanie w ujęciu zarówno medycznym, jak i prawnym. Pierwsze z nich pozwoli odpowiedzieć na pytanie, na

${ }^{1}$ Główny Urząd Statystyczny, Rocznik demograficzny 2018, Warszawa 2018, s. 364-365, http://stat.gov.pl/obszary-tematyczne/roczniki-statystyczne/roczniki-statystyczne/rocznikdemograficzny-2018,3,12.html (dostęp: 3.01.2019).

2 D.A. Cooley, In memoriam: Tribute to Ake Senning, pioneering cardiovascular surgeon, „Texas Heart Institute Journal” 27, 2000, nr 3, s. 234, https://www.ncbi.nlm.nih.gov/pmc/articles/ PMC101071/ (dostęp: 22.03.2019).

3 Wskazania do stałej stymulacji serca, „Folia Cardiologica” 6, 1999, supl. I, s. 1, https://journals.viamedica.pl/folia_cardiologica/article/view/24831/19882 (dostęp: 22.03.2019).

${ }^{4}$ M. Mirowski et al., Termination of malignant ventricular arrhythmias with an implanted automatic defibrillaton in human beings, „New England Journal of Medicine” 1980, nr 303, s. 322 324.

5 M. Trusz-Gluza et al., Wszczepienie automatycznego kardiowertera-defibrylatora. Opis przypadku, „Kardiologia Polska” 32, 1989, nr 7-9, s. 404-408. 
czym może polegać modyfikacja aktywności, z jakich przyczyn, kiedy oraz w jakim zakresie się jej dokonuje. Drugie zaś nawiązuje do problemu zgody uprawnionego podmiotu oraz zakresu obowiązku informacyjnego. Dodatkowo w świetle tytułowego zagadnienia powstaje konieczność rozważenia, czy, a jeśli tak, to w jakich przypadkach przedmiotowa terapia może być traktowana jako uporczywa. Na zakończenie przedstawione będą wnioski płynące z przeprowadzonej analizy.

\section{STATUS PRAWNY WSZCZEPIALNYCH URZĄDZEŃ DO ELEKTROTERAPII SERCA}

Do wyznaczenia ram przedmiotowych niniejszego artykułu należy określić status prawny wszczepialnych urządzeń do elektroterapii serca. Zgodnie z treścią art. 2 pkt 1 ustawy z dnia 20 maja 2010 roku o wyrobach medycznych (dalej: u.w.m. $)^{6}$ są one aktywnym wyrobem medycznym do implantacji definiowanym jako wyrób medyczny ${ }^{7}$ wraz z wszelkim wyposażeniem, którego funkcjonowanie zależy od źródła energii innej niż energia generowana bezpośrednio przez organizm ludzki lub przez siłę ciężkości, przeznaczony do wprowadzania, w całości lub w części, za pomocą zabiegu chirurgicznego lub innego zabiegu medycznego, do ludzkiego ciała lub, za pomocą zabiegu medycznego, do naturalnego otworu ciała, i który jest przeznaczony do pozostawania po zabiegu w ludzkim ciele lub naturalnym otworze ciała. Działanie tego rodzaju wyrobu może zależeć od energii elektrycznej skumulowanej w baterii jak przy stymulatorze serca czy kardiowerterze defibrylatorze ${ }^{8}$. Jednocześnie o zaliczeniu tych urządzeń do kategorii inwazyjnych wyrobów medycznych w rozumieniu art. 2 ust. 1 pkt 15 u.w.m. przesądza fakt, że są one wprowadzane w całości do wnętrza ludzkiego ciała przez otwory ciała albo przez jego powierzchnię. Dalsza kwalifikacja wyrobów medycznych według klas, uwzględniająca zastosowanie oraz ryzyko związane ze stosowaniem wyrobu, pozwala wyróżnić cztery kategorie: klasa I, klasa IIa, klasa IIb, klasa III. Jak wynika z treści art. 20 ust. 2 u.w.m., przy ocenie uwzględnia się takie czynniki, jak: czas i miejsce kontaktu z organizmem, stopień inwazyjności, działanie miejscowe oraz ogólnoustrojowe, spełnianą funkcję, zastosowane technologie. W wyniku zastosowania reguł

${ }^{6}$ Ustawa z dnia 20 maja 2010 roku o wyrobach medycznych, tekst jedn. Dz.U. z 2020 r. poz. $186 \mathrm{ze}$ zm. Natomiast od dnia 26 maja 2022 roku stosuje się rozporządzenie Parlamentu Europejskiego i Rady (UE) 2017/745 z dnia 5 kwietnia 2017 roku w sprawie wyrobów medycznych, zmiany dyrektywy 2001/83/WE, rozporządzenia (WE) nr 178/2002 i rozporządzenia (WE) nr 1223/2009 oraz uchylenia dyrektyw Rady 90/385/EWG i 93/42/EWG, Dz. Urz. UE L 117/1.

7 Por. art. 2 ust. 1 pkt 38 u.w.m.

${ }^{8}$ L. Ogiegło, [w:] R. Blicharz et al., Ustawa o wyrobach medycznych. Komentarz, Warszawa 2012, s. 30 . 
klasyfikacji wyrobów medycznych ${ }^{9}$ zarówno stymulatory serca, jak i kardiowertery-defibrylatory traktowane są jako wyroby medyczne klasy III, których zastosowanie wiąże się z największym potencjalnym ryzykiem ${ }^{10}$.

\section{RODZAJE WSZCZEPIALNYCH URZĄDZEŃ DO ELEKTROTERAPII SERCA}

Jak wskazano na wstępie, określone zaburzenia czynności serca leczone są przez wszczepienie pacjentowi elektronicznego urządzenia kardiologicznego, przy wystąpieniu wskazań medycznych do elektroterapii. Dalsze rozważania dotyczyć będą jedynie dwóch wybranych wszczepialnych urządzeń do elektroterapii: stymulatora serca oraz kardiowertera-defibrylatora ${ }^{11}$. Przyczyny dokonania takiego ich doboru wymagają wyjaśnienia. Stanowią one bowiem najczęściej implantowane urządzenia do elektroterapii. Ponadto na przykładach wskazanych powyżej urządzeń dostrzegalne są istotne różnice związane z prawnymi i medycznymi aspektami modyfikacji ich aktywności, wynikające ze spełniania odmiennych funkcji, a także związanych z tym różnorodnych potencjalnych następstw dla pacjenta.

Klasyczne urządzenia mają wielkość pudełka od zapałek ${ }^{12}$ i wagę około 30 70 g. Składają się one ze źródła energii elektrycznej (bateria urządzenia, wszczepiana zwykle w lewą okolicę podobojczykową) oraz elektrod (elektrody), wprowadzanych do serca przezżylnie. Głównym zadaniem stymulatora serca jest zapobieganie zbyt wolnej czynności serca wynikającej z dysfunkcji węzła zatokowego lub układu przewodzącego. Wyżej wymienionym stanom mogą towarzyszyć omdlenia, zawroty głowy czy niewydolność krążenia. Natomiast najważniejszą cechą ICD jest wykrywanie i leczenie groźnych arytmii komorowych, a tym samym zapobieganie nagłemu zgonowi sercowemu w tym mechanizmie ${ }^{13}$. Urządzenie to stosuje się w profilaktyce zarówno wtórnej (u pacjenta nastąpiła skuteczna reanimacja po zatrzymaniu krążenia w mechanizmie migotania komór/częstoskurczu komorowego), jak i pierwotnej (ryzyko groźnych arytmii komorowych jest u pacjenta wysokie).

Analizę różnic występujących między tymi urządzeniami rozpocząć należy od pozostających w bezpośredniej relacji z funkcjami przez nie pełnionymi odmiennych wskazań do ich wszczepienia. W wypadku PM będzie to wolna akcja rytmu serca (bradykardia), przy ICD zaś jest to ryzyko wystąpienia arytmii

9 Rozporządzenie Ministra Zdrowia z dnia 5 listopada 2010 roku w sprawie sposobu klasyfikowania wyrobów medycznych, Dz.U. Nr 215, poz. 1416.

10 Por. $\S 4$ ust. 3 pkt 4a rozporządzenia wskazanego w przypisie 9.

11 Inne urządzenia do elektroterapii to, przykładowo, bezelektrodowy PM, podskórny ICD.

12 Rozmiary stymulatorów są nieco mniejsze niż kardiowerterów-defibrylatorów.

13 Przyczynia się do 25\% zgonów z powodów sercowo-naczyniowych na świecie. 
komorowej oraz stan po nagłym zatrzymaniu krążenia w mechanizmie arytmii komorowej. Warunkuje to istotne odmienności widoczne odnośnie do funkcji pełnionych przez te urządzenia. Podstawowym zadaniem PM jest ocena częstości rytmu serca w trakcie każdego uderzenia i w przypadku zbyt wolnej częstości dostarczenie do mięśnia sercowego energii elektrycznej inicjującej depolaryzację komórek i skurcz serca. Natomiast ICD poza tą funkcjonalnością (której wielu pacjentów z ICD nie wymaga) jest wyposażony w funkcje wykrywania, różnicowania i przerywania arytmii. Będzie to miało znaczenie dla dalszych rozważań, albowiem w obecnie dostępnych ICD mogą być zastosowane dwa rodzaje terapii: niskoenergetyczna (stymulacja antytachyarytmiczna - ATP) oraz wysokoenergetyczna (defibrylacja wewnętrzna, a właściwie kardiowersja).

Istotnym kryterium wymagającym uwzględnienia przy dokonywanym zestawieniu jest także wpływ na jakość i komfort życia pacjenta funkcjonującego $\mathrm{z}$ urządzeniem do elektroterapii. Odnosząc się do konsekwencji dla pacjenta z implantowanym ICD, wskazać należy, że pacjent prawie nie odczuwa stymulacji antytachyarytmicznej. Drugi zaś rodzaj terapii - wysokoenergetyczna - może być dla przytomnego pacjenta odczuwalna jako dotkliwa, a nawracający charakter interwencji podejmowanych $w$ jej ramach przez urządzenie może powodować istotne pogorszenie komfortu i jakości życia. Wytworzenie wyładowania elektrycznego, przejawiającego się w bolesnym uderzeniu w klatkę piersiową, może być dla pacjenta źródłem dużego stresu. Natomiast funkcjonujący PM nie powinien skutkować pogorszeniem komfortu życia pacjenta. Zasadniczo nie wykazuje on wpływu na proces umierania, dla którego znaczenie mogą mieć adekwatne i nieadekwatne wyładowania ICD. Pod pojęciem pierwszych z nich rozumie się interwencje urządzenia w trakcie arytmii komorowej (ratujące życie pacjenta), drugie zaś są interwencjami indukowanymi przez czynnik inny niż komorowe zaburzenia rytmu serca ${ }^{14}$. Wskazuje się na istotny problem terapeutyczny wśród pacjentów z kardiowerterami-defibrylatorami, jakim jest liczba nieadekwatnych interwencji. Istnieją zasady medycznego postępowania mające na celu ich zmniejszenie, które można wdrożyć już w trakcie implantowania urządzenia ${ }^{15}$, za pomocą określonych sposobów jego programowania (przykładowo programowanie wysoko strefy migotania komór, również z wykorzystaniem strefy częstoskurczu komorowego), a także przez stosowanie optymalnej farmakoterapii czy wdrożenie zabiegowego leczenia zaburzeń rytmu (ablacja ${ }^{16}$.

W kontekście analizowanego zagadnienia istotne znaczenie ma też czas funkcjonowania danego urządzenia, gdyż jego upływ wiąże się z koniecznością wymiany baterii, czyli poddania pacjenta kolejnemu zabiegowi. Dla stymulatora

14 Arytmia nadkomorowa, a także sytuacje wynikające z uszkodzenia ICD, przykładowo elektrody.

15 A. Maciąg, Nieadekwatne interwencje kardiowertera-defibrylatora. Zapobieganie, https:// akademiaelektroterapii.pl/files/file-155-3.pdf (dostęp: 30.04.2019).

16 Ibidem. 
serca wynosi on zasadniczo około 8-10 lat, dla kardiowertera-defibrylatora zaś w przybliżeniu 6-8 lat od wszczepienia ${ }^{17}$.

\section{MEDYCZNE ASPEKTY MODYFIKACJI WSZCZEPIALNYCH URZĄDZEŃ DO ELEKTROTERAPII SERCA}

W niniejszej pracy pod pojęciem modyfikacji aktywności implantowanych urządzeń do elektroterapii rozumie się zmiany polegające na ograniczaniu poszczególnych funkcji lub ich całkowitą dezaktywację. Wskazania medyczne do wdrożenia takiego postępowania mogą wynikać z pogorszenia stanu zdrowia pacjenta ze względu na postępującą chorobę podstawową — niewydolność serca - albo ogólnego stanu zdrowia związanego z chorobami współistniejącymi (przykładowo chorobą nowotworową czy demencją). Na trudności terapeutyczne stojące przed lekarzami istotny wpływ ma niewątpliwie fakt, że aktualnie brakuje europejskich wytycznych w zakresie modyfikacji aktywności urządzeń, co będzie jeszcze rozważane w dalszej części pracy. Każdorazowa zmiana funkcjonowania urządzenia do elektroterapii powinna być poprzedzona dokonaną przez lekarza oceną korzyści i obciążeń wynikających z jego stosowania u konkretnego pacjenta w kontekście jego stanu ogólnego. Trwałą modyfikację aktywności lekarz przeprowadza w sposób nieinwazyjny i bezbolesny za pomocą odpowiedniego programatora, przez transmisję bezprzewodową lub przewodową do urządzenia znajdującego się pod skórą pacjenta.

\subsection{WSKAZANIA MEDYCZNE DO MODYFIKACJI URZĄDZEŃ DO ELEKTROTERAPII}

Wśród wskazań medycznych do wyłączenia ICD wymienia się stwierdzenie schyłkowej fazy choroby. Może to dotyczyć zarówno zaawansowanej choroby towarzyszącej, jak i pogorszenia niewydolności serca prowadzącej do nawracającej arytmii komorowej opornej na leczenie. Wówczas pacjent może nie akceptować uporczywej reanimacji, w tym interwencji antytachyarytmicznych urządzenia nisko- i wysokoenergetycznych. Należy podkreślić, iż dezaktywacja kardiowertera-defibrylatora nie jest jednoznaczna z wyłączeniem wszystkich funkcji urządzenia czy zaniechaniem wszelkich metod leczniczych oraz opieki nad pacjentem.

W przypadku pacjenta, u którego występują tachyarytmie komorowe (wykrywania szybkich rytmów serca), możliwe jest wyłączenie detekcji arytmii lub selektywne wyłączenie terapii wysokoenergetycznej, przy pozostawieniu terapii niskoenergetycznej, co do której u pacjenta istnieje szansa przerwania (raczej niebolesnego) częstoskurczu komorowego, ale już nie migotania komór, przy zapewnieniu dalszej opieki nad pacjentem.

17 Wpływa na to wiele czynników: stopień zależności pacjenta od funkcji stymulacji (PM, ICD), liczba interwencji urządzenia (ICD). 
Jeśli pacjent jest stymulatorozależny ${ }^{18}$, dezaktywacja urządzenia przyczyni się do zgonu pacjenta (eutanazja czynna). Natomiast u pacjentów mających własny rytm serca stymulacja poprawia jakość życia, zmniejszając objawy spowodowane zwolnieniem częstotliwości rytmu serca. Dodatkowo ciężka bradykardia nasila potencjalne ryzyko omdleń i wtórnych urazów, nasila objawy niewydolności serca oraz może prowadzić do rozwoju arytmii komorowej wywołanej bradykardią. Z reguły nie ma powodów do dezaktywacji stymulatora uzasadnionej zmniejszeniem cierpienia pacjenta. Jego wyłączenie może nastąpić po stwierdzeniu zgonu u pacjenta.

Jak wskazano uprzednio, interwencje ICD powodują wyładowania, odczuwalne przez pacjentów jako bolesne, co w istotny sposób może negatywnie wpływać na jakość życia pacjentów, wywołując u nich dyskomfort i niepokój. Jest to również potencjalna przyczyna ujawnienia się lub nasilenia stanów lękowych oraz depresji, co negatywnie wpływa na ogólne rokowanie pacjenta. Wyładowania nieadekwatne mogą być środkiem nieproporcjonalnym, gdyż jego efekty są niewspółmierne do cierpień fizycznych i psychicznych ponoszonych przez pacjenta. Jest to szczególnie dostrzegalne w schyłkowym okresie życia, kiedy interwencje ICD mogą nosić znamiona terapii uporczywej. W stanie agonii nawet skutecznie podjęta defibrylacja jedynie przywraca pacjenta do procesu umierania, wydłużając go i tym samym powodując dodatkowe cierpienia. Natomiast długość życia pacjenta z dezaktywowanym ICD zależy głównie od postępu choroby podstawowej, nie zaś samego faktu działania tego urządzenia. Jego wszczepienie nie jest bowiem metodą zapobiegania śmierci w ogóle, lecz jedynie formą prewencji nagłego zgonu sercowego (SCD). Zatem z przesłanek medycznych wynika, iż nawet skuteczna defibrylacja pacjenta u schyłku życia jedynie przedłuża proces agonii, albowiem występujące $\mathrm{w}$ tym stanie wyładowania warunkują pojawienie się następnych. Zgon pacjenta, jako nieunikniony, nastąpi w dłuższym czasie i w większym cierpieniu.

\section{PRAWNE ASPEKTY MODYFIKACJI URZĄDZEŃ DO ELEKTROTERAPII}

Po przeanalizowaniu ujęcia medycznego warto rozważyć kwestie prawne tego zagadnienia. Zgoda pacjenta lub innego uprawnionego podmiotu na określone działanie medyczne jest elementem koniecznym do uznania udzielenia świadczenia za prawnie dopuszczalne. Wraz z prawem do informacji o stanie zdrowia jest najistotniejszym przejawem realizacji prawa do samostanowienia ${ }^{19}$. Ze względu na przyjęcie koncepcji zgody poinformowanej najpierw analizowany będzie obowiązek informacyjny, a następnie podmioty uprawnione do wyrażenia zgody.

18 Nie ma własnego rytmu serca (poniżej 30 uderzeń/min po wyłączeniu stymulatora).

19 J. Bujny, Prawa pacjenta. Między autonomiq a paternalizmem, Warszawa 2017, s. 138. 
Uwzględnione zostaną dwie powiązane z sobą procedury medyczne, czyli sam zabieg implantacji urządzenia oraz następcza modyfikacja jego funkcji.

\subsection{OBOWIĄZEK INFORMACYJNY}

Implantacja urządzenia do elektroterapii zalicza się do kategorii zabiegu operacyjnego, metody leczenia i diagnostyki stanowiącej podwyższone ryzyko (art. 34 u.z.l.). Chodzi tu o ocenę ryzyka dla zdrowia i życia pacjenta w porównaniu z badaniami czy innymi działaniami mieszczącymi się w katalogu świadczeń zdrowotnych.

Korelatem powinności lekarza w zakresie realizacji obowiązku informacyjnego, zawartej w art. 31 u.z.l., jest prawo pacjenta do uzyskania informacji o swoim stanie zdrowia, co pozwala na aktywne i świadome uczestnictwo pacjenta $\mathrm{w}$ procesie terapeutycznym ${ }^{20}$. Ustalenie zakresu obowiązku informacyjnego jest szczególnie istotne w przypadku zabiegu operacyjnego (implantacja urządzenia do elektroterapii), albowiem zgodnie z treścią art. 34 ust. 2 u.z.l. przed wyrażeniem zgody lekarz ma obowiązek udzielenia informacji, której treść określa art. 31 u.z.l. W regulacji wskazano minimalny zakres przekazywanej pacjentowi informacji, uwzględniający różnorodne aspekty udzielania świadczenia zdrowotnego: stan zdrowia pacjenta, rozpoznanie, proponowane oraz możliwe metody diagnostyczne i lecznicze, dające się przewidzieć następstwa ich zastosowania albo zaniechania, wyniki leczenia, rokowania ${ }^{21}$. Należy podkreślić, że brak któregokolwiek z nich powoduje nieskuteczność zgody ${ }^{22}$. Sposób realizacji obowiązku informacyjnego, zarówno co do formy, jak i treści, powinien być przystępny, czyli dostosowany do możliwości percepcyjnych pacjenta wynikających z jego stanu zdrowia, wieku czy wykształcenia. Dodatkowo czas pozostawiony na podjęcie decyzji w przedmiocie wyrażenia zgody na świadczenie winien być adekwatny do jej wagi.

Odnosząc dotychczasowe rozważania ogólne do tytułowej problematyki, należy zauważyć, że szczególne znaczenie w kontekście zabiegu implantacji urządzenia do elektroterapii ma wiarygodna informacja dotycząca celu leczenia, następstw zastosowanej metody terapeutycznej oraz rokowania. Wystarczy generalne określenie możliwych zwykłych następstw, ze wskazaniem prawdopodobieństwa ich wystąpienia oraz ewentualnego wpływu, jaki mogą mieć na późniejsze funkcjonowanie organizmu ${ }^{23}$. Obowiązek informacyjny będzie bowiem przebiegał dwojako. Po pierwsze, powinien dotyczyć samego zabiegu implanta-

${ }^{20}$ M. Malczewska, [w:] Ustawa o zawodach lekarza i lekarza dentysty. Komentarz, red. E. Zielińska, Warszawa 2014, s. 577.

21 Wyrok SN z dnia 28 sierpnia 1973 roku, I CR 441/73, OSNC 1974, nr 7-8, poz. 131, w którym podkreślono, że zakres informacji i sposób pouczenia zależy od rodzaju zabiegu.

22 M. Safjan, Prawo i medycyna. Ochrona praw jednostki a dylematy wspótczesnej medycyny, Warszawa 1998, s. 69.

23 Wyrok SN z dnia 11 kwietnia 2006 roku, I CSK 191/05, Biul. SN 2006, nr 6, s. 9. 
cji, stosowanej metody, rodzaju wszczepianego urządzenia, ewentualnych konsekwencji, powikłań czy zaleceń pozabiegowych. Po drugie, wymaga odniesienia do długofalowych skutków zabiegu (plan leczenia, funkcjonowanie wszczepionego urządzenia), a tym samym poinformowania pacjenta o obowiązkowych wizytach w poradni według wskazanych terminów, przebiegu kontroli urządzenia (za pomocą programatora) czy konieczności okresowej wymiany baterii oraz ograniczeniach związanych z funkcjonowaniem z implantowanym urządzeniem.

Istotne znaczenie $\mathrm{w}$ analizowanym aspekcie ma uprzedni charakter realizacji obowiązku informacyjnego, zapoczątkowany przed wyrażeniem zgody na wszczepienie urządzenia. Wyjaśnienia wymagają bowiem nie tylko istota implantowanego pacjentowi PM czy ICD, sposób przebiegu interwencji czy stosowane znieczulenie, lecz także alternatywne metody leczenia. Nie można bowiem pominąć już na tym etapie konieczności wskazania na korzyści i obciążenia związane z funkcjonowaniem z implantowanym urządzeniem, w tym między innymi na możliwość odczuwalnych wyładowań ICD. Uzasadnione jest podkreślenie, że urządzenie towarzyszyć będzie pacjentowi do końca życia. Mogące wystąpić w przyszłości następstwa związane są między innymi z modyfikacją aktywności urządzenia, w tym problemami z utrzymaniem ich pełnej aktywności w schyłkowym okresie chorób przewlekłych. Będą to bowiem następstwa typowe, gdyż schorzenia stanowiące wskazanie do wszczepienia urządzenia (na przykład niewydolność serca) lub pojawiające się choroby towarzyszące mają postępujący charakter. Realizacja tych elementów w ramach obowiązku informacyjnego pozwoli pacjentowi na dostrzeżenie dalszej perspektywy stosowanego leczenia. Przedmiotowe rozmowy, prowadzone dopiero u schyłku życia, mogą być trudniejsze, niekiedy zaś niemożliwe do przeprowadzenia, między innymi z uwagi na trudności poznawcze występujące u pacjenta.

W świetle obowiązku informacyjnego należy zauważyć, że postępująca choroba może skutkować negatywnymi konsekwencjami, niewynikającymi z niewłaściwie dokonanego zabiegu implantacji czy funkcjonowania urządzenia, lecz naturalnego przebiegu choroby. Dynamika procesu chorobowego powinna zatem warunkować zakres przekazywanych pacjentowi informacji. Konieczność periodycznej weryfikacji pierwotnego planu leczenia uzasadnia okresowo przeprowadzane rozmowy o celach terapii z wykorzystaniem urządzenia, co następować może podczas kolejnych wizyt kontrolnych w poradni kontroli stymulatorów i kardiowerterów-defibrylatorów. Obowiązek wówczas spoczywałby na lekarzach kardiologach kontrolujących funkcjonowanie urządzeń. Zaostrzenie się objawów choroby, powtarzające się hospitalizacje czy zgłaszane dolegliwości powinny skłaniać do rozmowy z pacjentem na temat ewentualnych modyfikacji funkcji wszczepionych urządzeń w przyszłości. Wymaga to właściwego przygotowania do jej przeprowadzenia, co wiąże się z potrzebą edukacji lekarzy w ramach szkolenia specjalizacyjnego z zakresu kardiologii czy doskonalenia zawodowego w przedmiocie implantowanych urządzeń do elektroterapii serca i potencjalnej modyfikacji ich funkcjonowania, a także postępowania $\mathrm{z}$ tą grupą pacjentów. 


\subsection{ZGODA UPRAWNIONEGO PODMIOTU}

Jak wskazano, świadoma zgoda pacjenta (uprawnionego podmiotu) jest elementem koniecznym do uznania udzielenia świadczenia za prawnie dopuszczalne. Zgoda pacjenta na zabieg implantacji urządzenia, do której zastosowanie znajdzie art. 34 ust. 1 u.z.l., powinna przybrać formę pisemną. Jej wyrażenie nie jest jednoznaczne ze zgodą pacjenta na późniejszą modyfikację funkcji urządzenia. Każdorazowe programowanie, ograniczanie poszczególnych funkcji czy dezaktywacja powinny być przedmiotem odrębnej, świadomej zgody pacjenta. Zgoda na programowanie przybiera najczęściej postać dorozumianą, gdy w wyznaczonym terminie pacjent stawia się na kontrolnej wizycie w poradni, poddając się czynnościom wykonywanym przez lekarza, następnie odpowiednio udokumentowanym. Natomiast w wypadku wymiany baterii urządzenia, przykładowo ze względu na jej zużycie, konieczne będzie wyrażenie osobnej zgody na ten konkretny zabieg. Wydaje się, iż wtedy ponownie powinien być poruszony temat konsekwencji związanych z wymianą baterii urządzenia.

W analizowanym kontekście uwzględnić należy również prawo pacjenta do wyboru lub zatrzymania procedury medycznej, a także cofnięcia w każdym czasie wyrażonej uprzednio zgody. Przedmiotowa decyzja, będąca wyrazem autonomii woli, obejmuje różny zakres czynności: stanowisko pacjenta dotyczyć może całkowitej dezaktywacji urządzenia, wyłączenia poszczególnych funkcji, usunięcia urządzenia z ciała czy też odstąpienia od wymiany urządzenia, które nie pełni funkcji terapeutycznej ze względu na swoją wadliwość. Ocena zasadności wyłączenia urządzenia czy jego usunięcia podczas zabiegu ${ }^{24}$ będzie odmienna $\mathrm{w}$ odniesieniu do rodzaju urządzenia i zależności pacjenta od jego funkcjonowania. Wymaga również uwzględnienia funkcji urządzenia, która ma być modyfikowana. Najwięcej trudności rodzi wyłączenie funkcji stymulacji, albowiem zasadniczo nie jest ona przez pacjenta odczuwalna. U pacjenta stymulatorozależnego dezaktywacja urządzenia będzie bezpośrednią przyczyną zgonu. Natomiast u pozostałych pacjentów jej wyłączenie skutkować może obniżeniem komfortu życia czy wystąpieniem dodatkowych objawów (utrata przytomności, zasłabnięcie, zaburzenia funkcji poznawczych, duszność, bóle dławicowe związane z wysiłkiem). Zatem brak negatywnych konsekwencji związanych z aktywnością funkcji stymulacji utrudnia uzasadnienie jej wyłączenia ${ }^{25}$.

${ }^{24}$ Zabieg chirurgicznego usunięcia urządzenia na żądanie pacjenta, jeśli nie ma wskazań medycznych, jest nieuzasadniony, gdyż wiąże się z istotnym ryzykiem dla pacjenta (między innymi w zakresie powikłań pooperacyjnych). Natomiast dezaktywacja urządzenia następuje z zewnątrz, bez konieczności poddawania pacjenta zabiegowi.

25 J. Zakrzewska-Koperska, A. Przybylski, Prawne i etyczne aspekty implantacji kardiowerterów-defibrylatorów. Wybrane zagadnienia związane ze wszczepionymi urządzeniami, „W Dobrym Rytmie" 22, 2012, nr 1, s. 26. 
Natomiast decyzja o dezaktywacji ICD powinna być poprzedzona rozważeniem i zastosowaniem innych opcji terapeutycznych, takich jak optymalizacja jego działania czy farmakoterapia ${ }^{26}$.

Analizując problematykę zgody uprawnionego podmiotu, należy uwzględnić też okoliczność, że osoby u kresu życia, funkcjonujące z wszczepionym urządzeniem tworzą zróżnicowaną grupę. Są to bowiem pacjenci zarówno zdolni do podejmowania decyzji o charakterze medycznym, jak i niekompetentni z powodu ograniczenia funkcji poznawczych związanych z podeszłym wiekiem czy współwystępującymi u osób z chorobami układu krążenia zaburzeniami psychicznymi (lęk, depresja). Nie pozwala to zatem na przyjęcie jednolitego sposobu postępowania wobec wszystkich tych pacjentów. Pacjenci z pierwszej grupy realizują przysługujące im prawo do wyrażenia zgody w przedmiocie udzielania świadczenia zdrowotnego czy też odmowy leczenia, albowiem są one przejawem ich autonomii. Natomiast pacjenci niekompetentni zasadniczo nie mają możliwości wpływania na proces leczenia. Brakuje również instrumentów prawnych, które umożliwiłyby planowanie opieki medycznej na przyszłość. Nadal wiele wątpliwości budzi prawna dopuszczalność oraz skuteczność oświadczeń pro futuro czy ustanowienie pełnomocnika, na wypadek gdyby pacjent w przyszłości sam nie mógł podjąć decyzji. W świetle obowiązujących regulacji prawnych powstaje zatem pytanie, czy inny, poza pacjentem, podmiot mógłby wyrazić zgodę na modyfikację funkcji urządzenia. Opierając się na ogólnych przepisach w zakresie zgody zastępczej ${ }^{27}$, uprawniony byłby przedstawiciel ustawowy, a jeśli takiego nie ma, wówczas wymagane będzie uzyskanie zezwolenia sądu opiekuńczego. Natomiast gdy zwłoka spowodowana postępowaniem w sprawie uzyskania zgody groziłaby pacjentowi niebezpieczeństwem utraty życia, ciężkiego uszkodzenia ciała lub ciężkiego rozstroju zdrowia, lekarz może wykonać niniejsze czynności bez zgody przedstawiciela ustawowego pacjenta bądź zgody właściwego sądu opiekuńczego. W takiej sytuacji, w miarę możności, ma on obowiązek zasięgnąć opinii drugiego lekarza, najlepiej tej samej specjalności. Oprócz konieczności niezwłocznego zawiadomienia przedstawiciela ustawowego, opiekuna faktycznego lub sądu opiekuńczego o wykonywanych czynnościach lekarz powinien także pamiętać o dokonaniu stosownych adnotacji w dokumentacji medycznej pacjenta.

\section{FUNKCJONOWANIE ICD W KONTEKŚCIE UPORCZYWEJ TERAPII}

Uzasadnieniem do wyodrębnienia niniejszego podrozdziału jest okoliczność, zgodnie z którą funkcjonowanie ICD u pacjentów w schyłkowej fazie życia można rozpatrywać w aspekcie uporczywej terapii.

\footnotetext{
26 Ibidem.

27 Por. art. 34 ust. 3 i n. u.z.l.
} 
W polskim ustawodawstwie brakuje definicji legalnej tego pojęcia. W tym kontekście wskazać można na propozycję wypracowaną w 2008 roku w ramach Polskiej Grupy Roboczej ds. Problemów Etycznych Końca Życia, która zdefiniowała ją jako

stosowanie procedur medycznych, urządzeń technicznych i środków farmakologicznych w celu podtrzymywania funkcji życiowych nieuleczalnie chorego, które przedłuża jego umieranie, wiążąc się z naruszeniem godności pacjenta, w szczególności z nadmiernym cierpieniem; uporczywa terapia nie obejmuje podstawowych zabiegów pielęgnacyjnych, łagodzenia bólu i innych objawów oraz karmienia i nawadniania, o ile służą dobru pacjenta ${ }^{28}$.

Ze względu na ograniczone ramy przedmiotowe artykułu nie będzie w nim analizowane samo pojęcie uporczywej terapii.

Konieczność ochrony godności ludzkiej jako wartości nienaruszalnej oraz świadomość, że działania podejmowane w warunkach uporczywej terapii nie mają charakteru leczniczego, pozwalają przyjąć dopuszczalność zaniechania stosowania względem pacjenta procedur medycznych podtrzymujących funkcje życiowe. $\mathrm{Z}$ tych powodów obowiązek ochrony życia człowieka zawarty w art. 38 Konstytucji RP jest ograniczony ${ }^{29}$. W kontekście analizy konstrukcji umowy ubezpieczenia, a dokładnie art. 832 k.c., wskazano, że nie jest przyczynieniem się do śmierci ubezpieczonego wyrażenie przez uprawnionego prośby do lekarza o niepodejmowanie uporczywej terapii u ubezpieczonego lub też o rezygnację z niej. Wyraźnie oddzielono w tym kontekście powodowanie śmierci danej osoby od niestosowania lub zaprzestania uporczywych i szczególnie intensywnych działań służących jedynie sztucznemu podtrzymaniu życia ${ }^{30}$. Problematyka uporczywej terapii pojawia się też w piśmiennictwie przy analizie art. 150 k.k. (przestępstwo zabójstwa eutanatycznego). Podkreśla się, że nie może być traktowane jako zabronione pod groźbą kary zachowanie w postaci zaniechania stosowania procedur nadzwyczajnych, zdolnych przedłużyć jedynie etap umierania ${ }^{31}$. Lekarz, działając jako gwarant, ma obowiązek podjęcia działań mających charakter uporczywej terapii wyłącznie na wyraźne żądanie samego pacjenta ${ }^{32}$. Z czasem osoby starsze lub chore stają się coraz bardziej niedołężne, a cierpienia związane z chorobą od-

28 Projekt ustawy o ochronie genomu ludzkiego i embrionu ludzkiego oraz Polskiej Radzie Bioetycznej i zmianie innych ustaw z dnia 17 grudnia 2008 roku, http://www.law.uj.edu.pl/users/kk/ czytelnia/bio/Projekt.pdf (dostęp: 3.01.2019).

29 T. Sroka, [w:] Konstytucja RP, t. 1. Komentarz do art. 1-86, red. M. Safjan, L. Bosek, Warszawa 2016, s. 956.

${ }^{30}$ M. Orlicki, [w:] Kodeks cywilny, t. 2. Komentarz. Art. 450-1088, red. M. Gutowski, Warszawa 2016, s. 1119-1120.

31 A. Zoll, Zaniechanie leczenia - aspekty prawne, „Prawo i Medycyna” 2000, nr 5, s. 33; E. Zielińska, Powinności lekarza w przypadku braku zgody na leczenie oraz wobec pacjenta w stanie terminalnym, „Prawo i Medycyna” 2000, nr 5, s. 89.

32 M. Królikowski, [w:] Kodeks karny. Część szczególna, t. 1. Komentarz do artykutów 117221, red. R. Zawłocki, M. Królikowski, Warszawa 2017, s. 274. 
czuwają w intensywniejszy sposób. Wówczas najważniejsze jest zapewnienie warunków jak najgodniejszego starzenia się lub odchodzenia oraz przyniesienia ulgi w schyłkowych dolegliwościach, by nie narażać pacjenta na dodatkowe i niepotrzebne cierpienia ${ }^{33}$. Wskazuje się też, że nie ma uniwersalnej granicy pozwalającej traktować działanie lekarza jako uporczywą terapię, albowiem zależne będzie to przede wszystkim od schorzenia, na które cierpi pacjent. W tym kontekście M. Królikowski zauważa, że jeśli na podstawie doświadczenia lekarzy specjalistów możliwe jest określenie wystąpienia stanu przedagonalnego w obrazie danej choroby, stosowanie w tym momencie terapii agresywnej lub nadmiernie dolegliwych zabiegów pielęgnacyjnych można uznać za uporczywą terapię ${ }^{34}$.

Problematykę tę rozważyć należy także w aspekcie ustalania granic lekarskiego obowiązku podtrzymywania życia. W literaturze wskazuje się na konieczność uwzględnienia stanowiska pacjenta ${ }^{35}$, przejawiającego się w respektowaniu prawa zdolnego do wyrażenia woli pacjenta $\mathrm{w}$ przedmiocie żądania niepodejmowania lub zaprzestania działań mających na celu przedłużenie kończącego się życia ${ }^{36}$. Można też wskazać na regulację tego zagadnienia w Kodeksie Etyki Lekarskiej (dalej: KEL) ${ }^{37}$. W myśl art. 32 KEL w stanach terminalnych lekarz nie ma obowiązku podejmowania i prowadzenia reanimacji lub uporczywej terapii oraz stosowania środków nadzwyczajnych. Dodatkowo decyzja o zaprzestaniu reanimacji należy do lekarza i jest związana z oceną szans leczniczych.

Tytułową problematykę warto rozważyć w kontekście oceny postępowania lekarza przez pryzmat dyrektywy aktualnej wiedzy medycznej, której obiektywny charakter ma na celu zagwarantowanie pacjentowi świadczeń zdrowotnych na odpowiednio wysokim poziomie. Choć ze względu na dynamiczny postęp nauki pojęciu temu nie można nadać stałej treści, to niewątpliwie w jego zakresie mieści się zespół twierdzeń naukowych pozytywnie zweryfikowanych w środowisku medycznym, mających swoją podstawę w różnorodnych źródłach (podręczniki, czasopisma medyczne, wyniki badań klinicznych, wytyczne, zalecenia towarzystw naukowych, standardy medyczne oparte na dowodach naukowych). W związku z tym, że kryterium aktualności wiedzy medycznej może spełniać kilka procedur czy metod, nie jest uzasadnione tworzenie sztywnych algorytmów postępowania. Jednak wypracowanie pewnych wytycznych ułatwia lekarzom zapoznanie się z aktualnym stanem wiedzy medycznej, dając im wskazówki postępowania. W literaturze medycznej zauważa się, że przedstawiane zalecenia rozpoznawania

33 Ibidem.

34 Ibidem, s. 275. Autor przykładowo podaje stosowanie ICD, który w stanach zaawansowanych stymuluje serce wiązką fal elektrycznych kilkadziesiąt razy dziennie.

35 J. Bujny, op. cit., s. 224.

36 A. Zoll, Odpowiedzialność karna lekarza za niepowodzenie w leczeniu, Warszawa 1988, s. 28.

37 https://www.nil.org.pl/_data/assets/pdf_file/0003/4764/Kodeks-Etyki-Lekarskiej.pdf (dostęp: 15.04.2019). 
i leczenia danej choroby, choć tworzące fundament medycyny klinicznej, nie powinny być traktowane jako sztywny wzorzec postępowania, gdyż medycyna stale się rozwija, a każdy pacjent jest inny ${ }^{38}$. Jednakże aktualnie brakuje nawet wytycznych $\mathrm{w}$ przedmiocie postępowania z pacjentami z wszczepialnymi urządzeniami do elektroterapii serca, którzy znajdują się w schyłkowej fazie życia. Postuluje się, by planowanie opieki medycznej końca życia następowało przy aktywnym współdziałaniu kardiologów oraz specjalistów medycyny paliatywnej39. Stanowiska ekspertów w tej kwestii są niewiążące, stanowią bowiem ogólną wskazówkę dla lekarza. Ich stosowanie w konkretnym przypadku będzie przedmiotem decyzji lekarza, kierującego się między innymi dyrektywą aktualnej wiedzy medycznej. Warto wskazać na konsensus ekspertów Amerykańskiego Towarzystwa Zaburzeń Rytmu Serca oraz Europejskiego Towarzystwa Zaburzeń Rytmu Serca dotyczący monitorowania pacjentów z wszczepialnymi urządzeniami kardiologicznymi w zakresie techniki, wskazań, personelu, częstotliwości występowania tego zjawiska oraz rozważań etycznych (2008 rok), stanowisko Sekcji Niewydolności Serca Europejskiego Towarzystwa Kardiologicznego dotyczące opieki paliatywnej w niewydolności serca $(2009,2020)$, konsensus ekspertów EHRA działającego w ramach Europejskiego Towarzystwa Kardiologicznego (2010) czy stanowisko Amerykańskiego Towarzystwa Zaburzeń Rytmu Serca dotyczące postępowania $\mathrm{z}$ kardiologicznymi urządzeniami wszczepialnymi u pacjentów u kresu życia lub żądających przerwania elektroterapii (2010).

\section{WNIOSKI}

Ze względu na zasygnalizowane na wstępie czynniki powodujące wzrost liczby pacjentów z wszczepialnymi urządzeniami do elektroterapii w schyłkowej fazie życia coraz częściej lekarze stykać się będą nie tylko z problematyką modyfikacji ich aktywności, lecz także dalszego postępowania z tą grupą pacjentów. Tytułowe zagadnienie ma zatem bardzo istotny walor praktyczny, co uzasadnia pogłębioną dyskusję o charakterze interdyscyplinarnym.

Podsumowując niniejsze rozważania, podkreślić należy, że w dokonanej analizie wskazano na kilka zasadniczych elementów związanych z prawnymi i medycznymi aspektami modyfikacji aktywności wszczepialnych urządzeń do elektroterapii serca u pacjentów u kresu życia. W kontekście tego zagadnienia zidentyfikować można dwa podstawowe problemy. Pierwszy z nich wynika z istoty funkcjonowania kardiowertera-defibrylatora - jednego z rodzajów wszczepial-

38 A. Szczeklik, [w:] Podstawy EBM czyli medycyny opartej na danych naukowych dla lekarzy i studentów medycyny, red. P. Gajewski, R. Jaeschke, J. Brożek, Kraków 2008, s. 11.

39 T. Grądalski, M. Smyczyńska, Częściowa dezaktywacja wszczepialnego kardiowerteradefibrylatora u kresu życia, „Folia Cardiologica” 10, 2015, nr 4, s. 313. 
nych urządzeń. W schyłkowym okresie życia indukowane interwencje w zakresie funkcji kardiowersji czy defibrylacji mogą bowiem nosić znamiona terapii uporczywej, nie dając pacjentowi proporcjonalnej pomocy. Należy podkreślić, że celem modyfikacji aktywności ICD, polegającej na wyłączeniu niektórych jego funkcji, jest jedynie ograniczenie cierpień fizycznych i psychicznych pacjenta oraz nieprzedłużanie procesu umierania. Choć działania te mogą prowadzić do zgonu pacjenta, nie powinny być kwalifikowane jako wspomagane samobójstwo czy pomoc w dokonaniu eutanazji. Mając to na względzie, istotne znaczenie przypisać należy realizacji w stosunku do pacjenta obowiązku informacyjnego, czyli poinformowanie go jeszcze przed implantacją urządzenia o całokształcie konsekwencji związanych z jego funkcjonowaniem, w tym długofalowych skutkach oraz znaczeniu urządzenia w stosowanym planie leczenia. Obejmować powinien on nie tylko korzyści, lecz także ewentualne obciążenia, by pacjent był świadom tych następstw już przed przeprowadzeniem zabiegu wszczepienia. Natomiast kolejna ważna kwestia wiąże się ze zróżnicowaną pod względem podmiotowym grupą pacjentów, których dotyczyć może postępowanie w przedmiocie modyfikacji aktywności wszczepialnych urządzeń do elektroterapii. Są to bowiem zarówno pacjenci zdolni, jak i niezdolni do podejmowania decyzji o charakterze medycznym. W tej drugiej grupie pacjentów uwidacznia się problematyka sposobu realizacji prawa do wyrażenia zgody czy odmowy leczenia. Aktualnie brakuje bowiem rozwiązań dotyczących planowania opieki medycznej na przyszłość przez zastosowanie takich narzędzi jak testament życia czy pełnomocnictwo medyczne, co ogranicza w istotny sposób autonomię tych pacjentów. W świetle tytułowego zagadnienia wyraźnie dostrzegalny jest niewystarczający w stosunku do potrzeb stan obecnej regulacji w zakresie zagwarantowania realizacji podstawowych praw tej szczególnej grupy pacjentów.

\section{LEGAL AND MEDICAL ASPECTS OF THE MANAGEMENT OF CARDIAC IMPLANTABLE ELECTRONIC DEVICES IN PATIENTS TOWARD THE END OF LIFE}

\section{Summary}

At the beginning of our considerations, it should be pointed out that cardiovascular diseases are the reason for almost half of deaths in Poland. Some disorders of the cardiovascular system are treated with cardiac implantable electronic devices.

The aim of this paper is a comprehensive analysis of the issue regarding management of cardiac implantable electronic devices (peacemaker and cardioverter-defibrillator). In this respect it is significant to explain the legal status of these devices and the basic medical issues in the above scope (the type of devices, their similarities and differences). It is necessary for further consideration. In the scientific paper the management of cardiac implantable electronic devices both in legal and medical aspects is studied. In this context such problems as the patient's consent and the obligation to be provided with medical information are analysed. In addition it should indicate how, why, when 
and in which scope the devices could be managed. What is more, the subject matter is taken into consideration concerning medical futility.

Finally, the conclusions of the analysis are presented.

Keywords: patient's consent, the obligation to be provided with medical information, patient's autonomy, cardiac implantable electronic devices, medical futility

\section{BIBLIOGRAFIA}

Bujny J., Prawa pacjenta. Miedzy autonomiq a paternalizmem, Warszawa 2007.

Cooley D.A., In memoriam: Tribute to Åke Senning, pioneering cardiovascular surgeon, „Texas Heart Institute Journal" 27, 2000, nr 3, https:/www.ncbi.nlm.nih.gov/pmc/articles/PMC101071/.

Główny Urząd Statystyczny, Rocznik demograficzny 2018, Warszawa 2018, http://stat.gov.pl/obszary-tematyczne/roczniki-statystyczne/roczniki-statystyczne/rocznikdemograficzny-2018,3,12. html.

Grądalski T., Smyczyńska M., Częściowa dezaktywacja wszczepialnego kardiowertera-defibrylatora u kresu życia, „Folia Cardiologica” 10, 2015, nr 4.

Królikowski M., [w:] Kodeks karny. Część szczególna, t. 1. Komentarz do artykułów 117-221, red. R. Zawłocki, M. Królikowski, Warszawa 2017.

Maciąg A., Nieadekwatne interwencje kardiowertera-defibrylatora. Zapobieganie, https://akademiaelektroterapii.pl/files/file-155-3.pdf.

Malczewska M., [w:] Ustawa o zawodach lekarza i lekarza dentysty. Komentarz, red. E. Zielińska, Warszawa 2014.

Mirowski M., Reid P.R., Mower M.M., Watkins L., Gott V.L., Schauble J.F., Langer A., Heilman M.S., Kolenik S.A., Fischell R.E., Weisfeldt M.L., Termination of malignant ventricular arrhythmias with an implanted automatic defibrillaton in human beings, „New England Journal of Medicine" 1980, nr 303.

Ogiegło L., [w:] R. Blicharz, Ł. Chmielniak, L. Ogiegło, P. Ślezak, M. Tarnawski, L. Wilk, Ustawa o wyrobach medycznych. Komentarz, Warszawa 2012.

Orlicki M., [w:] Kodeks cywilny, t. 2. Komentarz. Art. 450-1088, red. M. Gutowski, Warszawa 2016.

Safjan M., Prawo i medycyna. Ochrona praw jednostki a dylematy wspótczesnej medycyny, Warszawa 1998.

Sroka T., [w:] Konstytucja RP, t. 1. Komentarz do art. 1-86, red. M. Safjan, L. Bosek, Warszawa 2016.

Szczeklik A., [w:] Podstawy EBM, czyli medycyny opartej na danych naukowych dla lekarzy i studentów medycyny, red. P. Gajewski, R. Jaeschke, J. Brożek, Kraków 2008.

Trusz-Gluza M., Religa Z., Wnuk-Wojnar A., Bochenek A., Szymkowiak-Rzechorzek E., Bochenek A., Sitarz R., Ciemniewski Z., Wszczepienie automatycznego kardiowertera-defibrylatora. Opis przypadku, „Kardiologia Polska” 32, 1989, nr 7-9.

Wskazania do stałej stymulacji serca, „Folia Cardiologica” 6, 1999, supl. I, https://journals.viamedica.pl/folia_cardiologica/article/view/24831/19882.

Zakrzewska-Koperska J., Przybylski A., Prawne i etyczne aspekty implantacji kardiowerterów-defibrylatorów. Wybrane zagadnienia zwiąane ze wszczepionymi urządzeniami, „W Dobrym Rytmie" 22, 2012, nr 1.

Zielińska E., Powinności lekarza w przypadku braku zgody na leczenie oraz wobec pacjenta w stanie terminalnym, „Prawo i Medycyna” 2000, nr 5.

Zoll A., Odpowiedzialność karna lekarza za niepowodzenie w leczeniu, Warszawa 1988.

Zoll A., Zaniechanie leczenia - aspekty prawne, „Prawo i Medycyna” 2000, nr 5. 


\section{AKTY PRAWNE I PROJEKTY AKTÓW PRAWNYCH}

Projekt ustawy o ochronie genomu ludzkiego i embrionu ludzkiego oraz Polskiej Radzie Bioetycznej i zmianie innych ustaw z dnia 17 grudnia 2008 roku, http:/www.law.uj.edu.pl/users/kk/ czytelnia/bio/Projekt.pdf.

Rozporządzenie Ministra Zdrowia z dnia 5 listopada 2010 roku w sprawie sposobu klasyfikowania wyrobów medycznych, Dz.U. Nr 215, poz. 1416.

Ustawa z dnia 20 maja 2010 roku o wyrobach medycznych, tekst jedn. Dz.U. z 2020 r. poz. 186 ze zm.

\section{ORZECZNICTWO}

Wyrok SN z dnia 28 sierpnia 1973 roku, I CR 441/73, OSNC 1974, nr 7-8, poz. 131. Wyrok SN z dnia 11 kwietnia 2006 roku, I CSK 191/05, Biul. SN 2006, nr 6, s. 9. 